\title{
UPAYA MENINGKATKAN PEMBELAJARAN KETERAMPILAN BOLAVOLI MELALUI PENDEKATAN SAINTIFIK BERBASIS PENILAIAN AUTENTIK
}

\author{
Oleh \\ Ernawati Can ${ }^{1)}$, Alnedral ${ }^{2)}$, Erizal $\mathbf{N}^{3)}$ \\ FakultasILmuKeolahragaanUniversitasNegeri Padang
}

\begin{abstract}
Abstrak:Berdasarkanpengamatanpenulis di SMP Negeri 2 Pekanbarupembeljaran PJOK padamateri bola volikurangmenarik.Tidakmenariknyapembelajaran PJOK terutamapadamateribolavoliperluditinjauulang,

karenahasilbelajarsiswabelumbisadikatakankegagalandalam proses pembelajaran yang dilakukan. Penelitianinibertujuanuntukmelihatimplementasipendekatansaintifikdengan proses penilaianautentikpadapembelajaranbolavoli di SMP Negeri 2 Pekanbaru.

Metodepenelitianiniyaitupenelitiantindakankelas (PTK) yang merupakansuatupencermatanterhadapkegiatanbelajar, Sebagaisubjekpenelitianiniadalahkelas VIII. 3, tahunpelajaran 2014/2015 denganjumlahsiswasebanyak 36 orang, terdiridari 15 laki-lakidan 21 perempuan. Adapunlangkah-langkahpelaksanaan PTK secaraprosedurnyaadalahdilaksanakansecarapastisipatifdandilanjutkande nganpenyusunanrencanatindakan, danpelaksanaantindakandalamsiklus.

Berdasarkanhasilpenelitian

yang dilakukanTerdapatpeningkatanketerampilan bola volimelaluipembelajarandenganpendekatansaintifikdengapenilaianautentik padapelajar SMP Negeri 2 Pekanbaru Riau. Hal initerbuktidarihasiltindakansikluspertama yang termasukkategorirendahartinyasebagaipelajar mampumelakukanteknikdasarketerampilan bola voli.
\end{abstract} Sedangkanpadasiklusketigaketerampilanberadapadakategoritinggi, yang berartijikadilihatdarijumlahpelajarkeseluruhanpeningkatanketerampilan bola volisudahterlihat. Terdapatpeningkatan yang sangatberartidalamperkembanganteknikdasar bola volidenganpembelajaranpendekatansaintifik.

Kata Kunci: HasilBelajar, PendekatanSaintifik, danPenilaianAutentik

PENDAHULUAN

Undang-Undang memiliki kekuatan spiritual keagamaan, Republik pengendalian diri, kepribadian, Indonesia Nomor 20 Tahun 2003 kecerdasan, akhlak mulia, serta tentang Sistem Pendidikan Nasional keterampilan yang diperlukan dirinya, menyatakan bahwa pendidikan adalah masyarakat, bangsa dan negara. Sesuai usaha sadar dan terencana untuk dengan tujuan dari sistem pendidikan mewujudkan suasana belajar dan nasional tersebut maka akan lahirlah proses pembelajaran agar lulusan yang bisa diandalkan dan pesertadidiksecara aktif mampu bersaing di level dunia. Maka mengembangkan potensi dirinya untuk dari itu kementerian pendidikan 
Vol. 2, No. 1, Mei 2017

membentuk berbagai jenis pendidikan untuk melakukan penilaian bisa sesuai formal dan non formal. Pendidikan dengan tuntutan kreteria ketuntasan formal adalah sekolah dan perguruan minimal.

tinggi, salah satu

Berdasarkan jumlah jam

Dalam materi bolavoli pertemuan yang ditambahkan diperkenalkan gerak dasar passingatas, seharusnya telah menambah proses passing bawah dan service. Masing- peningkatan atau penambahan gerak masing materi dilakukan secara dasar keterampilan pada siswa yang ada di dan berkelanjutan serta dinilai SMP Negeri 2 Pekanbaru. Namun, tidak berdasarkan materi pokok yang telah demikian halnya yang terjadi setelah diajarkan. Penilaian tersebut dilakukan proses penilaian yang dilakukan. Masih oleh pendidik berdasarkan tingkat banyak siswa yang mendapatkan hasil pencapaian yang telah ditentukan yang tidak sesuai dengan tujuan sebelumnya sesuai dengan persentase pencapaian standar kompetensi dan pencapaian yang juga dinamakan kompetensi dasar yang diharapkan. Dari dengan kriteria ketuntasan minimal. tinjauan 1 tahun pembelajaran yang Dengan adanya hal tersebut maka kita dilakukan, untuk hasil keterampilan bisa melihat tingkat keterampilan dalam gerak bolavoli masih $45 \%$ siswa yang berolahraga terutama olahraga bolavoli. mendapatkan hasil belajar yang sesuai Pembelajaran PJOK di SMP dengan tingkat pencapaian yang Negeri 2 Pekanbaru telah diharapkan, hal ini terbukti pada laporan melaksanakan proses pembelajaran hasil belajar siswa tahun ajaran dengan menggunakan kurikulum 2013 2013/2014 untuk nilai praktik siswa yang dimulai pada tahun ajaran 2013/2014. masih banyak belum mencapai kriteria Setiap materi diimplementasikan secara ketuntasan minimal (Rapor tahun ajaran berurutan dan sesuai dengan standar 2013/2014). Selanjutnya berdasarkan kompetensi lulusan (SKL), kompetensi pengamatan penulis yang sekaligus inti (KI), kompetensi dasar (KD) dan adalah guru PJOK di SMP Negeri 2 indikator.

Pekanbaru juga diduga disebabkan

Pada kurikulum sebelumnya kurang dikemasnya pembelajaran jumlah jam tatap muka untuk mata dengan metode pembelajaran yang pelajaran PJOK hanya 2 jam menarik, dan menyenangkan. Guru pertemuan. Dengan hanya 2 jam seringkali hanya monoton. Hal ini pertemuan tersebut maka siswa tidak disebabkan masih kurangnya dapat melaksanakan pelajaran PJOK pemahaman guru tentang strategi secara baik karena tidak cukup untuk mengajar yang ada pada penerapan pemberian materi secara berurutan. kurikulum 2013, sehingga siswa merasa Namun, pada kurikulum 2013 jumlah bosan dan malas untuk beraktivitas jam pertemuan menjadi 3 jam disebabkan karena pembelajaran yang pertemuan. Dengan adanya tidak menarik.

penambahan jam tersebut maka proses Tidak menariknya pembelajaran pembelajaran mata pelajaran PJOK bisa PJOK terutama pada materi bolavoli diberikan secara berurutan dan memiliki perlu ditinjau ulang, karena hasil belajar cukup waktu untuk pemahaman materi siswa belum bisa dikatakan kegagalan yang diberikan. Apabila materi yang dalam proses pembelajaran yang diberikan guru dapat dan bahkan bisa dilakukan. Hal tersebut bisa saja terjadi mencapai target pembelajaran, maka pada metode pembelajaran yang 
Vol. 2, No. 1, Mei 2017

digunakan serta proses penilaian yang

Pendidikan Jasmani merupakan dilakukan oleh pendidik/guru. bagian integral dari pendidikan secara

Metode ini memudahkan guru keseluruhan. Pendidikan jasmani adalah atau pengembangan kurikulum untuk pendidikan yang identik dengan aktivitas memperbaiki proses pembelajaran, yaitu gerak dan pelaksanaan pendidikan dengan memecah proses ke dalam jasmani harus diarahkan pada langkah-langkah atau tahapan- pencapaian tujuan pendidikan. Tujuan tahapansecara terperinci yang memuat pendidikan jasmani bukan aktivitas instruksi untuk siswa melaksanakan jasmani itu sendiri, tetapi untuk kegiatan pembelajaran. Pendekatan mengembangkan potensi siswa melalui saintifikdalam pembelajaran meliputi aktivitas jasmani dan mampu mengamati, menanya, mengembangkan seluruh aspek pribadi menalar,mencoba, membentuk jejaring manusia, dan tetap berpegang pada untuk semua mata pelajaran.

Pendekatan saintifik atau yang norma-norma pendidikan.

Sukintaka (2001:17) mengartikan dikenal dengan pendekatan ilmiah Pendidikan jasmani merupakan bagian merupakan pendekatan yang memiliki integral dari pendidikan total yang tahapan-tahapan yang dapat mencoba mencapai tujuan untuk mengembangkan segala hal yang mengembangkan kebugaran jasmani, terdapat dalam diri siswa secara mental, sosial, serta emosional bagi bertahap. masyarakat, dengan wahana aktivitas Penilaian autentik memiliki jasmani.

relevansi kuat terhadap pendekatan Pendidikan Jasmani merupakan ilmiah (scientific approach) dalam proses pendidikan yang memanfaatkan proses pembelajaran guna mewujudkan aktivitas jasmani yang direncanakan tujuan pembelajaran sesuai dengan secara sistematik bertujuan untuk tuntutan Kurikulum 2013. Karena mengembangkan ranah jasmani, penilaian kurikulum 2013 diharapkan keterampilan gerak, keterampilan mampu menggambarkan peningkatan berfikir kritis,dan meningkatkan individu hasil belajar siswa. Tahapan saintifik secara organik, neuromuskuler, dalam rangka mengobservasi, menalar, perseptual, kognitif, dan

mencoba, membangun jejaring, dan Mengacu pada uraian di atas, lain-lain. Penilaian autentik cenderung dapat di simpulkan bahwa Pendidikan fokus pada tugas-tugas kompleks atau Jasmani Olahraga dan Kesehatan kontekstual, memungkinkan siswa untuk (PJOK) merupakan bagian dari menunjukkan kompetensi mereka yang pendidikan secara keseluruhan yang meliputi sikap, pengetahuan, dan bertujuan untuk pencapaian tujuan dari keterampilan. Karenanya, penilaian pendidikan yang terdiri dari kognitif autentik sangat relevan dengan (pengetahuan), afektif (sikap), dan pendekatan saintifik dalam psikomotor (keterampilan) melalui pembelajaran. aktivitas jasmani atau aktivitas gerak.

Adanya metode penilaian serta Permainan bolavoli merupakan pendekatan saintifik dalam suatu permainan regu yang sangat pembelajaran pendidikan jasmani, menarik dan termasuk kedalam olahraga dan kesehatan terutama pada kelompok permainan menyerang dan materi bolavoli maka diharapkan hasil bertahan. Sama juga dengan belajar bisa lebih baik.

permainan- permainan yang lain, 
Vol. 2, No. 1, Mei 2017

permainan bolavoli mempunyai penerapan pendekatan saintifik dalam karakter- karakter tertentu dan pembelajaran melibatkan keretampilan dimainkan oleh dua regu yang proses seperti mengamati, berlawanan (Blume, 2004: 2). mengklasifikasi,

Keterampilan dasar permainan bolavoli Daryanto (2014:54) beberapa adalah kemampuan penguasaan teknik tujuan pembelajaran dengan dasar bolavoli meliputi passing atas, pendekatan saintifik adalah: (1) untuk pasing bawah, dan servis.Sebagaimana meningkatkan kemampuan intelek, karakteristiknya permainan bolavoli khususnya kemampuan berpikir tingkat mengandung unsur keterampilan gerak, tinggi siswa; (2) untuk membentuk yaitu berupa teknik- teknik memainkan kemampuan siswa dalam menyelsaikan bola didalam permainan bolavoli. suatu masalah secara sistematik; (3)

Kurikulum 2013 mendefinisikan terciptanya kondisi pembelajaran standar Kompetensi Lulusan (SKL) dimana siswa merasa bahwa belajar itu sesuai dengan yang seharusnya, yakni merupakan suatu kebutuhan; sebagai kriteria mengenai kualifikasi diperoleh hasil belajar yang tinggi; (5) kemampuan lulusan yang mencakup untuk melatih siswa dalam sikap, pengetahun dan keterampilan. mengomunikasikan ide-ide, khususnya Kurikulum 2013 yang menekankan pada dalam menulis artikel; dan (6) untuk dimensi paedagogik modern dalam mengembangkan karakter siswa.

pembelajaran menggunakan Berdasarkan uraian di atas dapat pendekatan ilmiah sebagai katalisator dilihat bahwa pendekatan saintifik utamanya atau perangkat atau apa pun merupakan suatu pendekatan ilmiah itu namanya. Pendekatan ilmiah dengan cara atau mekanisme untuk (scientific approach) diyakini sebagai mendapatkan pengetahuan dengan suatu cara perkembangan dan prosedur yang didasarkan pada suatu pengembangan sikap, keterampilan, metode ilmiah. Pembelajaran berbasis dan pengetahuan siswa dalam pendekatan saintifikini lebih efektif pendekatan atau proses kerja yang hasilnya dibandingkan dengan memenuhi kriteria ilmiah.

pembelajaran tradisional. Selanjutnya

Dalam pembelajaran saintifik kondisi pembelajaran dengan menekankan bahwa belajar tidak hanya pendekatan saintifik diharapkan untuk terjadi di ruang kelas, tetapi juga di mendorong siswa dalam mencari tahu lingkungan sekolah dan masyarakat. dari berbagai sumber melalui observasi, Selain itu, guru cukup bertindak sebagai dan bukan hanya diberi tahu.

scaffolding ketika anak/ siswa/ siswa Penilaian autentik merupakan mengalami kesulitan, serta guru bukan penilaian belajar yang merujuk pada satu-satunya sumber belajar. situasi atau konteks dunia nyata, Pembelajaran saintifik berkaitan dengan penilaian autentik untuk mengetahui metode saintifik sebagaimana ungkapan hasil dan prestasi belajar siswa, Sani (2014:50) bahwa "metode pendidik menerapkan kriteria dengan saintifik(ilmiah) pada umumnya konstruksi pengetahua, aktivitas melibatkan kegiatan pengamatan atau mengamati dan mencoba, dan nilai observasi yang dibutuhkan untuk prestasi luar pembelajaran. Dalam perumusan hipotesis atau penilaian autentik, selain memerhatikan mengumpulkan data". Sejalan dengan aspek kompetensi sikap (afektif), itu Daryanto (2014:51) menjelaskan kompetensi pengetahuan (kognitif) dan 
Vol. 2, No. 1, Mei 2017

kompetensi keterampilan (psikomotorik) Berdasarkan hasil penelitian serta variasi instrumen atau alat tes peningkatan keterampilan bermain bola yang digunakan juga harus voli pelajar SMP Negeri 2 Pekanbaru memperhatikan input, proses dan output Riau melalui pendekatan saintifik siswa. mengalami peningkatan setiap

Penilaian autentik memiliki pertemuannya. Menurut Ahmadi (2007: relevansi kuat terhadap pendekatan 20) "Teknik-teknik tersebut digunakan ilmiah dalam pembelajaran sesuai selama bermain, dimana permainan dengan tuntutan kurikulum 2013. bola voli memiliki aturan-aturan". Setiap Penilaian autentik cenderung fokus teknik gerak pada permainan bola voli pada tugas-tugas kompleks atau dapat dilakukan dengan baik jika konstektual, memungkinkan siswa untuk dilakukan dengan sungguh-sungguh menunjukkan kompetensi mereka dan berulang-ulang.

meliputi sikap, pengetahuan dan Perkembangan atau peningkatan keterampilan. keterampilan bola voli melalui METODE pendekatan saintifik ini selalu

Penelitiantindakankelasinidilaksa mengalami peningkatan pada setiap nakan di SMP Negeri 2 Pekanbaru Riau pertemuandari sebelum tindakan, siklus untukmatapelajaranPendidikanJasmanio I sampai siklus III. Pada tahap awal lahragadanKesehatan (PJOK). sebelum adanya tindakan dalam Sebagaisubjekpenelitianiniadalahkelas penelitian ini keterampilan bermain bola VIII. 3, tahunpelajaran 2014/2015 voli masih kurang, ini dapat dilihat dari denganjumlahsiswasebanyak 36 orang, persentase yang diperoleh, bahwa terdiridari 15 laki-lakidan 21 perempuan. pelajar belum mampu melakukan Penelitian ini dilaksanakan pada keterampilan gerak dan teknik bermain semester II tahun pelajaran 2014/2015, bola voli. Sikap tubuh dan dan yaitu bulan Januari sampai bulan penguasaan bola masih belum tepat Februari 2015. Dengan materi dan benar.

permainan bolavoli.

Jikadilihatuntuk rata-rata Tes

yang peningkatan keterampilan bola voli pada digunakanuntukmengukurhasilketerampi pelajar SMP Negeri 2 Pekanbaru Riau lanpermainan bola voliadalahTes Bola pada siklus I belum berjalan dengan volidariAAHPERD. Data yang baik karena masih banyak pelajar yang diperolehdarihasilobservasikegiatanbelaj mengalami kesulitan dalam melakukan armengajarakandianalisis. teknik dasar bola voli. Rata-rata nilai $\begin{array}{llll}\text { Setiapkegiatanpembelajaran yang yang didapatsebesar 8,72 } & \end{array}$ dilakukanmerupakanbahanuntukmenent ataudenganpencapaianbelumsampai ukantindakanberikutnya, $50 \% \quad$ karenahanyapada $\quad 43,61 \%$ disampingitujugaseluruh data untukpassingatas, $43,06 \%$ untukpassing digunakanuntukmengambilkesimpuland bawahdan $41,88 \%$ untukservis. aritindakan yang dilakukan. Padanilaipengetahuan, rata-rata Hasilanalisisiniakandimasukkandalamla pengetahuanpelajarmengenai bola $\begin{array}{lll}\text { poranpenelitianhasilbelajar } \quad \text { yang volidengannilaisebesar } & 77,31 \text {. }\end{array}$ akandiperolehdandianalisisuntukmelihat Padanilaisikap, rata-rata sikap yang perubahannya.

HASIL DAN PEMBAHASAN ditemukanpadapelajarmemilikipoin 2.08 denganpredikat $\mathrm{C}+$. 
Vol. 2, No. 1, Mei 2017

Pada siklus II keterampilan bola Kemudian untuk passing bawah voli pelajar sudah mulai tampak namun sudahmencapai $61,25 \%$ penguasaan belum memperlihatkan peningkatan keterampilan passing bawahnya yang signifikan. Peningkatan dengannilai rata-rata sebesar 12,25 dari keterampilan bermain bola voli pelajar total nilai 20 , dan untuk penguasaan SMP Negeri 2 Pekanbaru Riau melalui keterampilan service hanya 56,25\% pendekatan saintifik dibandingkan dengannilai rata-rata 22,25 dari total dengan kondisi pada siklus I nilai 40.

makapadasiklus II dari pertemuan Kemudianpadapertemuankedua pertama tampakkemampuan bermain peningkatankemampuanpelajarterusme bola voli pelajar SMP Negeri 2 ningkat, untukmateri passing atas Pekanbaru Riau masihbelummencapai mampu menguasai pembelajaran $50 \%$. Untuk keseluruhan pelajar pada sebesar $65,83 \%$ dengan rata-rata materi passing atas hanya mampu nilaipenguasaan keterampilan passing menguasai pembelajaran dengan hasil atasnyasebesar 13,17 dari total nilai 20 . $46,11 \%$ dengan rata-rata nilaisebesar Kemudian untuk passing bawah 9,22 dari total nilai 10 padapenguasaan sebesar67,08\% dengannilai rata-rata keterampilan passing atasnya, penguasaan keterampilan passing namunsudahada 10 pelajar yang bawahnya sebesar 13,42 dari total nilai mencapaikeberhasilan $\quad 50 \% 20$. Untuk penguasaan keterampilan untukpenguasaanpassing atasnya. service mencapai $62,08 \%$ dengannilai Kemudian untuk passing bawah sebesar rata-rata dari seluruh pelajar SMP $44,86 \%$ penguasaan keterampilan Negeri 2 Pekanbaru Riausebesar 24,83. passing bawahnya dari keseluruhan Peningkatankemampuansiswater pelajardengannilai rata-rata sebesar usterlihatmeningkathal ini terlihat pada 8,97 dan hanya 3 orang saja yang hasil belajar dengan penilaian yang mampu mencapai nilai keberhasilan telah disesuaikan dengan teknik dasar $50 \%$ yakni nilai 10 dari total nilai yang ingin dinilai. 20.Kemudian untuk penguasaan sudahmencapailebihdari 75\% keterampilan service hanya $43,61 \%$ ataulebihdaribatas KKM yang dengannilai rata-rata 17,44 dari total ditentukan. Untuk keseluruhan pelajar nilai 40 dari seluruh pelajar SMP Negeri pada materi passing atas sudah mampu 2 Pekanbaru Riau. menguasai

pembelajaran

Pada siklus III peningkatan sebesar77,36\% ataudengannilai rataketerampilan bola voli sudah mulai rata pencapaianpenguasaan tampak dan meningkat. keterampilan passing atasnyasebesar Padapertemuanpertamasudahada yang 15,47 dari total nilai 20 . Kemudian untuk mencapaipadanilaipenguasaanpembelaj passing bawah aransebesarlebihdari $60 \%$. Untuk berhasilmencapai81,67\% dengannilai keseluruhan pelajar pada materi passing rata-rata 16,33 dari total atas hanya mampu menguasai nilaipenguasaan keterampilan passing pembelajaran dengan hasil $59,17 \%$ bawahnya 20 . Untuk penguasaan dengannilai rata-rata $\quad 11,83$ keterampilan service mencapai $77,92 \%$ dimanahanya 3 orang pelajarsaja yang dengannilai rata-rata dari seluruh pelajar mendapatnilairendahyakninilai 10 dari SMP Negeri 2 Pekanbaru total nilai 20 padapenguasaan Riauadalahsebesar 31,17 dari total nilai keterampilan passing atasnya. 40 untukpembelajaranservis.. 


\section{DAFTAR RUJUKAN}

Ahmadi, Nuril.

PanduanOlahragaBolavoli.

Surakarta: Era PustakaUtama
Dimyati dan Mujiono. 2013. Belajar dan Pembelajaran. Jakarta: Rineka Cipta.

2007.

Gusril. 2011. Model Pengembangan motorik Pada siswa sekolah Dasar. Padang: UNP Press

Alnedral. 2008. Strategi Spektrum gaya Hamalik, Oemar. 2013.Proses Belajar

Pengajaran Pendidikan Jasmani

Olahraga dan kesehatan. Padang. UNP Press

Alnedral. $2014 . \quad$ Strategi

PembelajaranPendidikan Jasmani Olahraga dan kesehatan. Padang. FakultasllmuKeolahragaanUnivers itasNeger Padang

Arikunto, Suharsimi. 2009. Penelitian Tindakan Kelas. Jakarta: Bumi Aksara

Basuki, Ismet. 2014. Asesmen Pembelajaran. Bandung: PT. Kunandar. 2014. Penilaian Autentik. Remaja Rosdakarya

Blume, Gunter. 2004. Permainan Bola Ma'mun, AmungdanSubroto. 2003. Voli Training-Teknik-Taktik. Alih Bahasa Syafruddin. Padang: FIK UNP

BSNP. 2006. Panduan Penyusunan KTSP Jenjang Pendidikan Dasar dan Menengah. Jakarta: Depdiknas

Daryanto. 2013. Pendekatan Pembelajaran Saintifik Kurikulum 2013. Yogyakarta: Gava Media Daryanto, dkk. 2014. Pengembangan Perangkat Pembelajaran. Yogyakarta: Gava Media Jakarta: PT Rajawali Pers Mengajar. Jakarta: Bumi Aksara

Kemendikbud. 2014. Buku guru Pendidikan jasmani olahraga dan kesehatan. Jakarta. Pusat Kurikulum dan Perbukuan, Balitbang, Kemendikbud

Kristiyanto, Agus. 2010. Penelitian Tindakan Kelas Dalam Pendidikan Jasmani dan Kepelatihan Olahraga. Surakarta: UNS Press Kunandar. 2010. Penelitian Tindakan Kelas. Jakarta: PT Rajawali Pers PendekatanKeterampilanTaktisdal amPembelajaranBolavoli, Konsep, \&MetodePembelajaran. Jakarta: DirjenOlahragaDepdiknas

Mosston, Muska and Ashworth, Sara. 2008. Teaching Physical Education. First Online Edition

Permendikbud No. 66 Tahun 2013. StandarPenilaianPendidikan.

Sani, Abdullah. 2014. Pembelajaran Saintifik Untuk Implementasi Kurikulum 2013. Jakarta: Bumi Aksara 